Eliciting a predatory response in the Eastern Corn snake (Pantherophis guttatus) using live and inanimate sensory stimuli: Implications for managing invasion

Journal: International Journal of Pest Management

Corresponding author:

Co-author 1:

Co-author 2:

\section{J. O. WORTHINGTON-HILL}

31 The Lizard, Wymondham, Norfolk, NR18 9BH. UK

+44 (0) 7843870462

John.daboia@gmail.com

R. W. YARNELL

Nottingham Trent University, School of Rural, Animal and Environmental Sciences, Brackenhurst, Southwell, Nottinghamshire, NG25 0QF. UK

+44(0) 1158485333

Richard.yarnell@ntu.ac.uk

L. K. GENTLE

Nottingham Trent University, School of Rural, Animal and Environmental Sciences, Brackenhurst, Southwell, Nottinghamshire, NG25 0QF. UK

+44(0)1158485253

Louise.gentle@ntu.ac.uk 


\title{
Eliciting a predatory response in the Eastern Corn snake (Pantherophis guttatus) using live and inanimate sensory stimuli: Implications for managing invasion
}

\begin{abstract}
:
North America's Eastern corn snake (Pantherophis guttatus) has been introduced to several islands throughout the Caribbean and Australasia where it poses a significant threat to native wildlife. Invasive snake control programs often involve trapping with live bait, a practice that, as well as being costly and labour intensive, raises welfare and ethical concerns. This study assessed corn snake response to live and inanimate sensory stimuli in an attempt to inform possible future trapping of the species and the development of alternative trap lures. We exposed nine individuals to sensory cues in the form of odour, visual, vibration and combined stimuli and measured the response (rate of tongue-flick [RTF]). RTF was significantly higher in odour and combined cues treatments, and there was no significant difference in RTF between live and inanimate cues during odour treatments. Our findings suggest chemical cues are of primary importance in initiating predation and that an inanimate odour stimulus, absent of simultaneous visual and vibratory cues, is a potential low-cost alternative trap lure for the control of invasive corn snake populations.
\end{abstract}

Keywords: Corn snake, invasive, chemoreception, sensory stimuli, trapping, lure.

\section{1: Introduction}

Invasive species are one of the greatest drivers of biodiversity loss (Lodge, 1993;

Mooney \& Hobbs, 2000; Drake \& Hunt, 2008). Consequently, huge effort is focused on control and eradication programs to limit the impact on ecosystems. Unlike many other organisms, invasive snakes are a fairly recent phenomenon (Pitt et al., 2005), fuelled largely by the pet trade (Pimentall et al., 2000; Lever, 2003). Their elusive and resilient nature makes invasive snakes particularly difficult to manage (Vice \& Pitzler, 2000; Sakai et al. 2001).

Invasive snakes can significantly disrupt native ecosystems, and in some cases have caused irreversible damage (Elton, 1958; Pitt et al., 2005). This is particularly true on islands where indigenous species have usually evolved in the absence of strong competition, herbivory, parasitism or predation and possess various undesirable 
predispositions (Savidge, 1987; Rodda \& Fritts, 1992, 1999; Wiles et al., 1995). The brown tree snake (Boiga irregularis), accidentally introduced to the island of Guam after WWII, is a prime example. It quickly reached unprecedented numbers and decimated native avifauna including the extinction of 12 bird species (Savidge, 1987; Engbring \& Fritts, 1988; Wiles et al., 2003). The case of the brown tree snake should be a precautionary tale of the necessity to act immediately on invasive species. In most cases, effective management of invasive snakes involves controlling and reducing numbers (Clavero \& Garcia-Berthou, 2005); efforts often rely on traps to capture snakes (Engeman et al., 1998; Rodda et al., 1999). Snake traps are also commonly employed in pest removal (often glue-based shelter traps [Knight, 1986]) and for the purposes of research (Jenkins et al., 2003; Dorcas \& Wilson, 2009).

The eastern corn snake (Pantherophis guttatus) occupies an extensive range throughout the eastern and southern central United States, into northern Mexico. It is reported as nocturnal, crepuscular and diurnal depending largely on latitude and time of year (Greene, 1997). Corn snakes are slender and agile, killing prey by constriction. In common with other snakes of the Colubridae family, they are generalist, opportunistic hunters (Mullin \& Gutzke, 1999) found in a diverse range of habitats (Ernst \& Ernst, 2003), traits typical of invasive snakes (Rodda et al., 1999; Pit et al., 2005). Owing to its docile nature and simple husbandry, the species is very popular in the pet trade and widely bred in captivity.

Through escaped and released pets and transportation with cargo, the "introduced range" of the corn snake has reached a global scale. Corn snakes were first recorded in the Bahamas in the mid-1990s and have subsequently spread to several islands where they are known to have established breeding populations (Platenberg, 2007; Questel \& Vitry, 2012). Corn snakes predate on the rarest bird in the Bahamas, 
the bahama nuthatch (Sitta pusilla insularis), and represent a major threat to its survival and that of numerous other vulnerable endemic birds, lizards and snakes (Platenberg, 2007; Hayes et al. 2004; Giery, 2013). In the greater Caribbean region, there are records from 16 different islands and islets within the Lesser Antilles, Cayman Islands, Virgin Islands, and continental islands off the northern coast of South America (Powell \& Henderson, 2003; Perry et al., 2003; Platenberg, 2007; Questel and Vitry, 2012). Recently, an individual was recorded for the first time on Abaco Island in 2013 (Giery, 2013), indicating the continued spread of the species. Populations are also reported in places as disparate as Taiwan (Shiau et al., 2006), parts of Europe, South Africa (Global Invasive Species Database, 2010) and South America (Eterovic \& Duarte, 2002; Lever, 2003). In Australia, corn snakes are declared a "Class 1 Pest Species" meaning they are subject to eradication (Page et al., 2008; Fisher \& Csurhes, 2009; IUCN ISSG, 2010). As well as pressure through predation and competition, they are a potential host for foreign diseases (Xioa et al. 2004) and are shown to hybridise with other closely related species (Pitt et al. 2005). The management of introduced corn snake populations does not currently involve trapping though in many parts of the world, particularly the greater Caribbean region, aggressive control measures are warranted.

\section{1: $\quad$ Sensory perception and prey detection}

Sensing mechanisms in snakes gather a variety of environmental cues and, in terms of predation, provide critical information about the type and location of prey (Cowles \& Phelan, 1958; Dullemeijer, 1961; Proske, 1969; Dukkas \& Ellner, 1993). The importance of one stimulus over another varies according to species as sensory perception is linked with diet and predatory strategy (Chiszar et al., 1981; Vincent et 
al., 2005; Saviola et al., 2012). In the process of foraging, most snakes utilise mainly vision, chemoreception and ground-borne vibrations.

Determination of a predominate sense and how well snakes can adjust to changes in the predatory environment has received some attention (mainly in the colubrid genera Thamnophis, Nerodia and Boiga) along with sensory analyses of predation and prey-trailing in pit vipers (Crotalinae) (Chiszar et al., 1977a,b; Chiszar, 1978; Furry et al., 1991; Kardong, 1993; Parker \& Kardong, 2006). Furthermore, numerous studies document heavy reliance on chemical cues during predation (Halpern \& Frumin, 1979; Kubie \& Halpern, 1979; Halpern \& Kubie, 1983; Saviola et al. 2012), with vision, and interaction between the two modalities also being important (Eichholz \& Koenig, 1992; Neal et al., 1993).

Early research demonstrated the importance of prey movement for predation in snakes (Herzog \& Burghardt, 1974; Burghardt, 1978; Burghardt \& Denny, 1983) and visual cues have been shown to be crucial in the foraging behaviour of gray rat snakes (Pantherophis obsoleta) until chemical cues are available (Mullin \& Cooper, 1998). Indeed, predators generally orient towards moving prey (Burghardt, 1966; Smith \& Watson, 1972; Lindberg, 2000) and the current effectiveness of live bait lures on Guam may indicate the significance of movement for colubrid snakes. However, Shivik \& Clarke (1997) demonstrated that carrion is also effective in attracting brown tree snakes into traps.

Nevertheless, identification of the importance of a single sensory cue may be an oversimplification of foraging behaviour. In a natural predatory situation, different sensory cues are often presented simultaneously and may interact with each other. Shivik (1998) and Hansknecht \& Burghardt (2010) showed that the loss of a single stimulus resulted in diminished interest in brown tree snakes and mangrove saltmarsh 
snakes (Nerodia clarkii compressicauda) respectively, perhaps demonstrating a synergy between sensory cues. This effect is reported elsewhere in snakes and has influenced the design of multisensory lures (Lankford, 1989; Chiszar, 1990; Shine et al., 2003). Snakes, especially those with a broad diet, are likely to switch between sensory modalities, reacting to single cues based on the context in which they are presented (Chiszar, 1990). Therefore, the loss of one particular cue may not be equivalent to the loss of another. Of importance to sensory lure design is the knowledge that the nature of a cue and how it is represented may also influence its relative significance (Shivik \& Clarke, 1997).

\section{2: $\quad$ Aims and justification}

Invasive snake control programs that incorporate trapping rely heavily on researchbased understanding of species' sensory perception and predatory behaviour. Despite widespread concern over invasive corn snake populations and the need for eradication programs on a number of islands, there are very few studies into corn snake sensory behaviour and none address trap lure design for the species' control and management. Here, we assess the sensory cues involved in prey detection and their relative importance, test for synergistic interaction between combined cues, and compare response to live (mouse) and inanimate (model) sensory stimuli. We discuss the possibility of artificial, inanimate sensory attractants for corn snakes and their potential as alternatives to multi-sensory lures and live bait in trapping programs.

\section{0: Materials and Methods}

\section{1: $\quad$ Subjects and housing}


We measured the response of adult corn snakes (Pantherophis guttatus) $(\mathrm{n}=9)$, consisting of four female and five male snakes, to live and inanimate sensory cues in a controlled environment. All snakes were bred in captivity and handled regularly. Snakes were maintained separately in $60 \times 60 \times 120 \mathrm{~cm}$ vivariums at $25-30^{\circ} \mathrm{C}$ on a natural lightdark cycle with appropriate enclosure design. Normal diet consisted of one or two defrosted white mice (Mus domesticus) per week, depending on snake size.

The study was conducted at two different locations, The Seal and Bird Rescue Trust (SBRT - Riddlington, Norfolk) and Nottingham Trent University (NTU) Animal Unit, which between them provided the snakes for this study. For live treatments a different mouse $(n=4)$ was used for each of the trials. Therefore, each snake was exposed to the same mouse for the same treatment.

\section{2: $\quad$ Experimental design}

During experiments, controlled and independent variables were standardised between locations. Ambient temperature was maintained at $25-30^{\circ} \mathrm{C}$, movement of observers was minimised and the laboratory well lit. Experiments were conducted in a room absent of other animals to minimise inadvertent sensory stimulation.

Prior to experiments none of the snakes were fed for a period of 21 days (though they were provided with water) reflecting natural variation in food availability and to encourage a behavioural response. Trials ran for a two week period with a different treatment randomly assigned to each day. To prevent the effects of treatment order, each snake was tested repeatedly using a Latin square cross-over design (Ott, 1993) to randomly assign snakes to five groups representing sensory cues. Live cues were tested in week one and inanimate cues in week two, summing 90 trials in total. 


\section{3: $\quad$ Trial procedure}

For each treatment, the snake was transferred to the laboratory and placed under a hide in a large vivarium $(60 \times 60 \times 120 \mathrm{~cm})$ devoid of substrate, climbing material, hides, water bowls or heating apparatus. The stimulus representing a sensory cue, live or inanimate, was placed in a clear plexiglass container $(15 \times 15 \times 30 \mathrm{~cm})$ in a separate room to prevent premature stimulation, particularly odour. In order to minimise odour transfer, disposable gloves were worn at all times. The snake was allowed to acclimatise for 15 minutes in the large vivarium with no disturbance before placing the stimulus container in the centre of the vivarium and removing the hide, thus exposing the snake to the intended stimulus. During trials absent of chemical cues the stimulus container featured an airtight lid. The same equipment was used for all snakes and all treatments, having been disinfected and air-dried between trials.

Snake response to the introduced stimulus was measured visually by counting and recording the total number of tongue-flicks in a five minute period (rate of tongue flick, RTF). Tongue-flicking in snakes is a stimulus-seeking behaviour and is activated by detection of sensory cues (Burghardt, 1970; Chiszar et al. 1981; Burghardt \& Denny, 1983; Saviola et al., 2011). Therefore, RTF is a convenient measure of a snake's response to external stimuli. The general behaviour of mice and snakes were observed to ensure none were under stress during experiments. This study was granted ethical approval by Nottingham Trent University Ethics Committee.

\section{4: $\quad$ Treatments}


Sensory cues were partitioned to ensure the stimulus affecting RTF was the cue being tested, i.e. to prevent sensing with any other mode. To this end, each stimulus required a specific setup. Bedding was placed in containers for all treatments to replicate current live traps and to standardise the stimulus container between cues.

Live cues - During live visual treatments a mouse was placed in an airtight container on a foam mat to prevent odour transmission and to inhibit vibrations. One-way mirror film prevented the mouse from seeing the snake. A top-vented faunarium was used for odour trials; foam matting inhibited vibrations and cardboard surround blocked visual contact. During live vibratory trials, a mouse was placed in the air-tight faunarium and on a glass surface to promote the transmission of vibrations from mouse to snake. Again, cardboard surround prevented visual contact.

Inanimate cues - A similar arrangement was used for inanimate trials. During the visual treatment the mouse was replaced by a toy mouse of similar size and colour, and animated with a piece of wire to simulate live mouse movement. For the odour treatment the faunarium contained only soiled mouse bedding. For vibratory trials wire was used to tap lightly on the glass surface in an aberrant manor. No stimulus was provided during the control treatment, though the container was present.

A further treatment in both live and inanimate trials combined all stimuli.

\section{5: Data analysis}

We assessed the difference in RTF between treatments, and between live and inanimate cues using a two-way ANOVA. Paired t-tests compared RTF between live and inanimate stimuli for visual, vibration and odour treatments, as well as combined and 
"no cues" trials. We also assessed differences in response to live odour and combined stimuli, and inanimate odour and combined stimuli with paired t-tests.

\section{0: $\quad$ Results}

Observed behaviour ranged from no interest in sensory cues, to intense predatory behaviour and tracking mice in containers. Although several snakes probed at containers, none were observed striking.

Accounting for live and inanimate cues, there was a significant difference in RTF between treatments (two-way ANOVA: $\mathrm{F}_{4,80}=113.04, \mathrm{P}<0.001 ;$ Fig. 1 ) with the greatest response to odour and combined stimuli and the lowest response to vibration and control stimuli. Live cues elicited significantly higher RTF than inanimate cues (two-way ANOVA: $\mathrm{F}_{1,80}=4.05, \mathrm{P}=0.048$ ) though the difference varied between stimuli. RTF differed significantly in visual $(\mathrm{T}=3.25, \mathrm{~N}=9, \mathrm{P}=0.012)$ but not vibration $(\mathrm{T}=1.99, \mathrm{~N}=9, \mathrm{P}=0.082)$ or odour $(\mathrm{T}=0.45, \mathrm{~N}=9, \mathrm{P}=0.667)$ treatments. There was a significant difference in RTF between live and inanimate stimuli in both combined $(\mathrm{T}=2.12, \mathrm{~N}=9, \mathrm{P}=0.38)$ and "no cues" $(\mathrm{T}=2.12, \mathrm{~N}=9, \mathrm{P}=0.21)$ treatments. Finally, this study detected no significant difference between odour and combined cues in either live $(\mathrm{T}=0.20, \mathrm{~N}=9, \mathrm{P}=0.844)$ or inanimate $(\mathrm{T}=-1.03, \mathrm{~N}=$ $9, \mathrm{P}=0.335)$ treatments, suggesting no synergy.

\section{0: Discussion}

This study shows that sensory modalities vary in their importance for prey detection in corn snakes. Odour was clearly the most effective stimulus and the most attractive sensory cue. It is a long-held understanding that chemical perception is conducive to 
effective foraging in snakes (Chiszar et al., 1981; Shivik, 1998; Lindberg et al., 2000; Shivik et al., 2000) though our results suggest odour is of overriding importance to corn snakes in prey detection.

While chemical signals propagate slowly from the source and are less directional than light, they transmit around obstacles and in darkness, are available long after the source was present, and have the greatest potential range of any stimulus (Gillam, 2012) allowing snakes to track and locate prey over larger distances. Odour may therefore be more useful for prey detection in wide-ranging foraging snakes, such as corn snakes (Sperry \& Taylor, 2008), though it is believed visual stimuli are important for guiding strikes once in close proximity to prey (Chiszar et al., 1977; Grace \& Woodward, 2001). Vision has been shown to be important in prey searching (Mullin \& Cooper, 1998) but it is theorised to be most effective immediately pre-strike, providing instantaneous and accurate imaging. In the case of potentially dangerous prey, predatory strikes must be precisely targeted to prevent a retaliatory attack. We observed tracking behaviour only during visual trials once snakes were in close proximity to mice, supporting this theory.

Contrary to studies with other species (Drummond, 1979; Lankford, 1989; Heinen, 1995), corn snakes demonstrated a strong attraction to the source of the stimulus without visual cues suggesting they are not of primary importance in prey detection. Chemical cues, even in the absence of all other stimuli, elicited the greatest response with snakes displaying a distinctly heightened mode of appetitive behaviour culminating in several individuals probing the stimulus container; behaviour not seen in other treatments. Similarly, Saviola et al. (2012) demonstrated significant increase in predatory response to odour stimuli for four other colubrid species suggesting that for many snakes, chemical cues play primary importance in initiating predation. 
Although several individuals tracked mice during visual trials, predatory response was significantly reduced and prey movement did not provoke the behaviour seen in brown tree snakes (Lindberg, 2000; Shivik et al. 2000). The importance of movement as a predatory stimulus for corn snakes, however, cannot be omitted as the lower RTF in visual trials could be attributed to interpretation as container walls or mirror film (not used in previous studies, e.g. Chiszar et al., 1998; Shivik, 1998; Shivik, 2000) may have obscured the snakes' vision and meant visual cues were not accurately represented.

Vibration trials elicited the lowest RTF and were ineffective, though again cues may have been confounded by underrepresentation as other snake species have demonstrated some predatory response to prey vibrations alone (Shivik, 1998; Mullin \& Gutzke, 1999; Shivik et al., 2000). The role of vibrations for prey detection in corn snakes may be more important than our findings show, especially when visual cues are absent, e.g. at night. However, in the presence of visual and chemical stimuli, the influence of prey vibrations on predatory behaviour can be assumed to be secondary in corn snakes and minimal in this study.

It is assumed that a more complete sensory image of a prey item should elicit greater RTF. Yet, unlike Haverley \& Kardong (1996), Shivik (1998), Lindberg et al. (2000) and Shivik et al. (2000), we found no synergistic interaction between combined stimuli. Consistent with Saviola et al. (2012), we detected no significant difference between combined stimuli and odour alone supporting evidence further that chemical cues are of primary importance for prey detection in corn snakes.

Inanimate visual and vibratory stimuli were unable to elicit predatory behaviour such as the tracking of mice in live visual trials. Although previous studies have shown that predators will select aberrant movement over normal movement (Gluesing, 1983), 
our attempts to replicate the sensory cues of live mice using inanimate visual and vibratory cues elicited the lowest RTF. In previous studies where movement was shown to be an effective stimulant, a motorised model was used that perhaps more realistically represented live prey (Lindberg, 2000; Shivik et al. 2000). However, of significance to this study is the finding that odour stimuli emitted from a live source elicited no significant difference in RTF than odour from an inanimate source. Furthermore, an inanimate odour stimulus alone was as effective in eliciting predatory behaviour as simultaneous visual, chemical and vibratory stimuli from a live mouse.

\section{1: Implications for trap design}

Corn snakes demonstrate an unequivocal and strong attraction to chemical cues. The effectiveness of inanimate odour stimuli presents the potential for chemical cues alone to serve as effective trap lures without multisensory stimuli in the form of a live mouse or complex model. This finding complements those of Frits et al. (1989) and Shivik \& Clarke (1997) who captured brown tree snakes with odour alone. Therefore, a simple lure of prey odour may lead to similar capture rates for corn snakes as traps incorporating live mice, though further experiments in field conditions are needed to test this hypothesis.

\section{2: $\quad$ Study limitations}

As discussed, snake response may have been confounded by issues of stimulus interpretation. It is necessary to more thoroughly investigate the effects of visual and vibratory signals and the context in which they are presented, as well as to elucidate the influence of the look and movement of prey. It would be useful to investigate response 
to alternative odours such as prey faeces, urine and blood, and dead and decaying prey. Ontogenetic diet progression in corn snakes should also be addressed as there are obvious implications for sensory attractants.

This study presumes that RTF is an effective and accurate measure of interest correlated with attractiveness of stimuli. However, when tracking mice during visual trials there were moments when tongue flicking ceased despite continued interest in the stimulus. Therefore, amount of time with head oriented towards source of stimulus may be a more suitable measure.

Although outcomes from previous studies have proven consistent between laboratory and field experiments (Shivik, 1998), snakes react to a stimulus based on the context in which it is presented (Rodda et al., 1999; Shivik et al., 2000). Therefore, the present study should be replicated under field conditions to ascertain whether odour is still the key stimulus and the efficacy of chemical cues in encouraging snakes to enter traps.

\section{3: Conclusions}

The findings of this study suggest it will be difficult to develop simple yet effective inanimate visual and vibratory attractants for corn snakes based on the stimuli provided by live mice. However, snakes showed greatest interest where chemical cues were available, suggesting an inanimate chemical stimulus, without simultaneous visual and vibratory stimuli, may be an effective sensory lure. It is proposed that for Corn snakes, and species with similar predatory behaviour, alternative low-cost trap designs (e.g. adapted ground-level funnel traps and shelter traps) baited only with prey odour may be as successful as cage traps with more complete multisensory lures. If field trials 
confirm that this is the case there will be implications for potential future snake

eradication programmes. Prey odour alone may not only be sufficient but very effective, thereby deeming live bait redundant and addressing animal welfare issues, as well as reducing labour costs associated with trapping of this nature.

\section{0: Acknowledgements}

We are grateful to Cat Sanderson and Emma Broome at Nottingham Trent University Animal Unit, and Beverley Cossey and David Carr at the Seal and Bird Rescue Trust for providing snakes and allowing access for data collection. We would also like to acknowledge Donald Strydom and staff at Khamai Reptile Centre for their useful comments. This study was granted ethical approval by Nottingham Trent University Ethics Committee.

\section{0: $\quad$ References}

Bealor, M., \& Saviola, A. (2007). Behavioural complexity and prey-handling ability in snakes: gauging the benefits of constriction. Behaviour. 144: 907-929.

Burghardt, G. M. (1967). Chemical cue preference of inexperienced snakes: comparative aspects. Science. 157: 718-721.

Burghardt, G. M. (1969). Comparative prey-attack studies in newborn snakes of the genus Thamnophis. Behaviour. 33: 77-114.

Burghardt, G. M. (1970). Chemical perception in reptiles. In Johnston, J. W., Moulton, D. G. and Turk, A. (Eds.), Advances in chemoreception. I. Communication by chemical signals. Appleton-Century-Crofts, New York. 241-308.

Burghardt, G. M. (1975). Chemical prey preference polymorphism in newborn garter snakes Thamnophis sirtalis. Behaviour. 52: 202-225.

Burghardt, G.M., Denny, D. (1983). Effects of prey movement and prey odor on feeding in garter snakes. Zeitschrift für Tierpsychologie. 62: 329-347.

Chiszar, D. (1978). Chemosensory searching for wounded prey by Rattlesnakes is released by striking: a replication report. Herp. Review. 9: 54-56.

Chiszar, D. (1990): The behavior of the brown Treesnake, Boiga irregularis: a study in applied comparative psychology. Pages 101-123 in D. Dewsbury, editor. Contemporary issues in comparative psychology. Sinauer Assoc., Sunderland, Massachusetts.

Chiszar, D., Taylor, S., Radcliffe, C., Smith, H., \& O’Connell, B. (1981). Effects of Chemical and Visual Stimuli upon Chemosensory Searching by Garter Snakes and Rattlesnakes. Journal of Herpetology. 15: 415-423. 
Chiszar, D., Fox, K. \& Smith, H.M. (1992). Stimulus control of predatory behavior in the brown tree snake (Boiga irregularis) IV. Effect of mammalian blood. Behavioral and Neural Biology. 57: 167-169.

Chiszar, D., Radcliffe, D. W., \& Scudder, K. M. (1977). Analysis of the behavioral sequence emitted by rattlesnakes during feeding episodes. I. Striking and chemosensory searching. Behav. Biol. 21: 418-425.

Clavero, M., \& García-Berthou, E. (2005). Invasive species are a leading cause of animal extinctions. Trends in Ecology and Evolution. 20/3: 110.

Drake, D. \& Hunt, T. (2009). Invasive Rodents on Islands: Integradting Historical and Contemporary Ecology. Biological Invasions. 11: 1483-1487.

Dorcas, M., \& Willson, J. (2009). Innovative methods for studies of snake ecology and conservation. In: Snakes: Ecology and Conservation. Mullin, S., and Seigel, R. (Eds.), 5-37. Ithaca, NY: Cornell University Press.

Dukas, R. \& Ellner, S. (1993). Information Processing and Prey Detection. Ecology. 74: 1337-1346.

Eichholz, M. W. \& Koenig, W. D. (1992). Gopher snake attraction to birds' nests. Southwest. Nat. 37: 293-298.

Elton, C. S. (1958). The Ecology of Invasions by Animals and Plants. Methuen. 181.

Engbring, J., \& Fritts, T. (1988). Demise of an insular avifauna: the brown tree snake on Guam. Transactions of the Western Section of the Wildlife Society. 24: 31-37.

Engeman, R.M., Rodriguez, D., Linnell, M., \& Pitzler, M. (1998). A review of the case histories of the brown tree snakes (Boiga irregularis) located by detector dogs on Guam. International Biodeterioration \& Biodegradation. 42: 161-165.

Engeman, R.M., Linnell, M., Pochop, P. \& Gamboa, J. (1998). Substantial reductions of brown tree snake (Boiga irregularis) populations in blocks of land on Guam through operational trapping. International Biodeterioration \& Biodegradation. 42: 167-171.

Engman, R. M., \& Vice, D. S. (2000). Standardizing the evaluation of brown tree snake trap designs. USDA National Wildlife Research Center - Staff Publications.Paper. 182.

Engeman, R.M., Vice, D., Nelson, G., \& Muna, E. (2000). Brown tree snakes effectively removed from a large plot of land on Guam by perimeter trapping. International Biodeterioration \& Biodegradation. 45: 139-142.

Engeman, R. M., \& Vice, D. S. (2001). Objectives and integrated approaches for the control of brown tree snakes. Integrated Pest Management Reviews. 6: 59-76.

Ernst, CH, \& Ernst, EM. (2003). Snakes of the United States and Canada. Smithsonian Books, Washington, D.C.

Eterovic, A. \& Duarte, M. (2002). Exotic snakes in São Paulo City, southeastern Brazil: why xenophobia? Biodiversity and Conservation. 11: 327-339.

Fisher, P., \& Csurhes. S., (2009). American Corn Snake: Pest Animal Risk Assessment. Queensland Primary Industries and Fisheries., Queensland Government. 
Fritts, T. (1989). Preventing the introduction of the brown tree snake Boiga irregularis to the state of Hawaii. Report to Hawaii Dep. Of Agriculture from the U.S. Fish and Wildlife Service, Washington, D.C.

Fritts, T., \& Leasman-Tanner, D. (2001). The brown tree snake on Guam: How the arrival of one invasive species damaged the ecology, commerce, electrical systems, and human health on Guam: A comprehensive information source. U.S. Department of the Interior.

Furry, K., Swain, T., \& Chiszar, D. (1991). Strike-induced chemosensory searching and trail following by prairie rattlesnakes (Crotalus viridis) preying upon deer mice: chemical discrimination among individual mice. Herpetologica. 17: 69-78.

Giery, S. (2013). First Records of Red Corn snakes (Pantherophis guttatus) from Abaco Island, The Bahamas, and Notes on Their Current Distribution in the Greater Caribbean Region. IRCF Reptiles \& Amphibians. 20: 36-39.

Gillam, E. (2012). An introduction to animal communication. Nature Education Knowledge. 3: 70.

Global Invasive Species Database, (2010). Elaphe guttata, reptile: Distribution. Available at: http://www.issg.org/database/species/distribution.asp?si=1572\&fr=1\&sts=\&lang=E N [Accessed September 2010]

Gluesing, E.A . (1983). Collared lizard predation: the effects of conspicuous morphology and movement. Copeia. 1983: 835-837.

Grace, M. \& Woodward, O. (2001). Altered visual experience and acute visual deprivation affect predatory targeting by infra-red imaging boid snakes. Brain Res. 919: 250-258.

Greene, H. (1997): Snakes, the evolution of mystery in nature. University of California Press, Berkeley.

Halpern, M., \& Frumin, N. (1979). Roles of the vomeronasal and olfactory systems in prey attack and feeding in adult garter snakes. Physiol. Behav. 22: 1183-1189.

Halpern, M., \& Kubie, J. L. (1983). Snake tongue flicking behavior: Clues to vomeronasal system function. In Silverstein, R. M., and Muller-Schwarze, D. (Eds.), Chemical signals III. Plenum Publishing Corp, New York. 45-72.

Hansknecht, K.A., Burghardt, G.M. (2010). Stimulus control of lingual predatory luring and related foraging tactics of Mangrove Saltmarsh Snakes (Nerodia clarkii compressicauda). J. Comp. Psycol. 124: 159-165.

Hayes, W. K., Barry, R. X., Mckenzie, Z., \& Barry, P. (2004). Grand Bahama's Brownheaded Nuthatch: A Distinct and Endangered Species. Bahamas Journal of Science. 12: $21-28$.

Heinen, J.T. (1995). Predator cues and prey responses: A test using eastern garter snakes ( Thamnophis s. sirtalis) and American toads (Bufo a. americanus). Copeia. 738-741.

IUCN/SSC Invasive Species Specialist Group (ISSG). (2010). A Compilation of Information Sources for Conservation Managers. 
Jenkins, C., McGarigal, K., \& Gamble, L. (2003). Comparative effectiveness of two trapping techniques for surveying the abundance and diversity of reptiles and amphibians along drift fence arrays. Herpetological Review. 34: 39-42.

Kardong, K.V. (1993). The Predatory Behavior of the Northern Pacific Rattlesnake (Crotalus viridis oreganus): Laboratory versus Wild Mice as Prey. Herpetologica. 49: 457-463.

King, R.B. (1987). Color Pattern Polymorphism in the Lake Erie Water Snake, Nerodia sipedon insularum. Evolution. 41: 241-255.

Knight, J. (1986). A humane method for removing snakes from dwellings. Wildl. Soc. Bull. 14: 301-303.

Kubie, J. L. \& M. Halpern. (1979). The chemical senses involved in garter snake prey trailing. J. Comp. Physiol. Psych. 93: 648-667.

Lankford, J. D. (1989). Stimulus control of foraging Brown Tree Snakes (Boiga irregularis). Journal of Colorado-Wyoming Academy of Science. 21: 12.

Lever, C. (2003). Naturalized Reptiles and Amphibians of the World. Oxford University Press. New York.

Lindberg, A.C., Shivik, J.A. \& Clark, L. (2000). Mechanical Mouse Lure for Brown Treesnakes. Copeia. 3: 886-888.

Linnell, M. A., Engeman, R. M., Pitzler, M. E., Watten, M. O., Whitehead, G. F., \& Miller, R. C. (1998). An evaluation of two designs of stamped metal trap flaps for use in the operational control of brown tree snakes (Boiga irregularis). The Snake. 28: $14-18$.

Lodge, D. M. (1993). Biological invasions: lessons for ecology. Trends Ecol. Evol. 8: 133-37

Mooney, H., \& Hobbs, R. (2000). Invasive Species in a Changing World. Island Press, England.

Mortensen, H., \& Dupont, Y. (2008). Snake in paradise: Disturbance of plant reproduction following extirpation of bird flower-visitors on Guam. Biological Conservation. 141: 2146-2154.

Mullin, S.J., \& Cooper, R.J. (1998). The foraging ecology of the snake Elaphe obsolete spiloides - visual stimuli facilitate location of arboreal prey. Am. Midl. Nat. 140: 397-401.

Mullin, S.J. \& Gutzke, W. (1999). The Foraging Ecology of the Gray Rat Snake (Elaphe obsoleta spiloides). I. Influence of Habitat Structural Complexity When Searching for Mammalian Prey. Herpetologica. 55: 18-28.

Neal, J. C., Montague, W. G., \& James, D. A. (1993). Climbing by black rat snakes on cavity trees of red-cockaded woodpeckers. Wildl. Soc. Bull. 21: 160-165.

Ott, E. (1993). Chaos in dynamical systems. Cambridge University Press, Cambridge.

Page, A., Kirkpartick, W., \& Massam, M. (2008). Corn Snake (Elaphe guttata) risk assessment for Australia. Department of Agriculture and Food, Western Australia.

Parker, M.R. \& Kardong, K.V. (2006). The Role of Airborne and Substrate Cues from Non-Envenomated Mice during Rattlesnake (Crotalus oreganus) Post-Strike Trailing. Herpetologica. 62: 349-356. 
Perry, G., Pierce, J., Griffin, D., Van Buurt, G., \& Lazell, JRW. (2003). Elaphe guttata guttata (Corn snake), Herpetological Review. 34: 264.

Pimentel, D., Lach, L., Zuniga, R., \& Morrison, D. (2000). Environmental and economic costs of nonindigenous species in the United States. BioScience. 50: 5365.

Pitt, W., Vice, D., \& Pitzler, M. (2005). Challenges of Invasive Reptiles and Amphibians. Proceedings of the 11th Wildlife Damage Management Conference.

Platenberg, R.J., (2007). Impacts of introduced species on Island ecosystem: non-native reptiles and amphibians in the US Virgin Islands. USDA National Wildlife Research Center Symposia Managing Vertebrate Invasive Species.

Platenberg, R. J., \& Boulon, Jr, R. (2006). Conservation status of reptiles and amphibians in the U.S. Virgin Islands. Applied Herpetology. 3: 215-235.

Powell, R. \& Henderson, R. (2003). A second set of addenda to the checklist of West Indian Amphibians ad Reptiles. Herpetological Review. 34: 341-345.

Questel \& Vitry (2012). Pantherophis guttatus (Corn Snake). Distribution. Caribbean Herpetology. 37: 1.

Rodda, G., Fritts, T., \& Reichel, J. (1991). The distributional patterns of reptiles and amphibians in the Mariana Islands. Micronesica. 24: 195-210.

Rodda, G. H., \& Fritts, T. H., (1992). The impact of the introduction of the colubrid snake Boiga irregularis on Guam's lizards. J. Herpetol. 22: 166-174.

Rodda, G. H., Fritts, T. H., Mccoid, M. J., \& Campbell Iii, E. W. (1999). An Overview of the Biology of the Brown Treesnake (Boiga irregularis), a Costly Introduced Pest on Pacific Islands. Wildlife Damage Management, Internet Center for USDA National Wildlife Research Center-Staff Publications. 44-80.

Rodda, G., Sawai, Y., Chizar, D., \& Tanaka, H. (1999): Problem snake management: The habu and the brown treesnake. Cornell University Press, Ithaca, New York, USA.

Sakai, A., Allendorf, F., Holt, J. Lodge, D., Molofsky, J., With, K., Baughman, S., Cabin, R., Cohen, J., Ellstrand, N., McCaulley, D., O’Neil, P., Parker, I., Thompson, J., \& Weller, S. (2001). The population biology of invasive species. Annu. Rev. Ecol. Syst. 32: 305-32.

Savidge, J.A. (1987). Extinction of an island forest avifauna by an introduced snake. Ecology. 68: 660-668.

Saviola, A.J., Lamoreaux,W.E., Opferman. R., \& Chiszar D. (2011). Chemosensory response visual

of the threatened eastern indigo snake (Drymarchon couperi) to chemical and

stimuli of Mus musculus. Herpetol. Conserv. Biol. 6: 449-454.

Saviola, A. J., McKenzie, V., \& Chiszar, D. (2012). Chemosensory responses to chemical and visual stimuli in five species of colubrid snakes. Acta Herpetologica. 7: 91-103.

Shiau, T., Hou, P., Wu, S., \& Tu, M. (2006). A Survey on Alien Pet Reptiles in Taiwan. Taiwania. 51: 71-80. 
Shine, R., Phillips, B., Waye, H., LeMaster, M., \& Mason, R. (2003). Chemosensory Cues Allow Courting Male Garter Snakes to Assess Body Length and Body Condition of Potential Mates. Behavioral Ecology and Sociobiology. 54: 162-166.

Shivik, J. A., \& Clark, L. (1997). Carrion seeking in brown tree snakes: importance of olfactory and visual cues. Journal of Experimental Zoology. 279: 549-553.

Shivik, J.A. (1998). Brown Tree Snake Response to Visual and Olfactory Cues. The Journal of Wildlife Management. 62: 105-111.

Shivik, J.A., Bourassa, J. \& Donnigan, S.N. (2000). Elicitation of Brown Treesnake Predatory Behavior Using Polymodal Stimuli. The Journal of Wildlife Management. 64: 969-975.

Smith, G. C., \& Watson, D. (1972). Selection patterns of corn snake, Elaphe guttata, of different phenotypes of the house mouse ,Mus musculus. Copeia. 529-532.

Sperry, J., \& Taylor, C. (2008). Habitat use and seasonal activity patterns of the great plains ratsnake (elaphe guttata emoryi) in central texas. The Southwestern Naturalist. 53: 444-449.

Vincent, S., Shine, R., \& Brown, G. (2005). Does foraging mode influence sensory modalities for prey detection in male and female file snakes, Acrochordus arafurae. Animal Behaviour. 70: 715-721.

Wiles, G. J., Aguon, C. F., Davis, G. W., \& Grout, D. J. (1995). The status and distribution of endangered animals and plants in northern Guam. Micronesica. 28: 31-49.

Wiles, G., Bart, J., Beck, R. Jr., \& Aguon, C. (2003). Impacts of the Brown Tree Snake: Patterns of Decline and Species Persistence in Guam's Avifauna. Conservation Biology. 17: 1350-1360.

Xiao, L., Ryan, U. M., Graczyk, T. K., Limor, J., Li, L., Kombert, M., Junge, R., Sulaiman, I. M., Zhou, L., Arrowood, M. J., Koudela, B., Modry, D., \& Lal, A. A. (2004). Genetic Diversity of Cryptosporidium spp. in Captive Reptiles. Applied and Environmental Microbiology. 70: 891-89 


\section{0: $\quad$ Figures}

Figure 1:

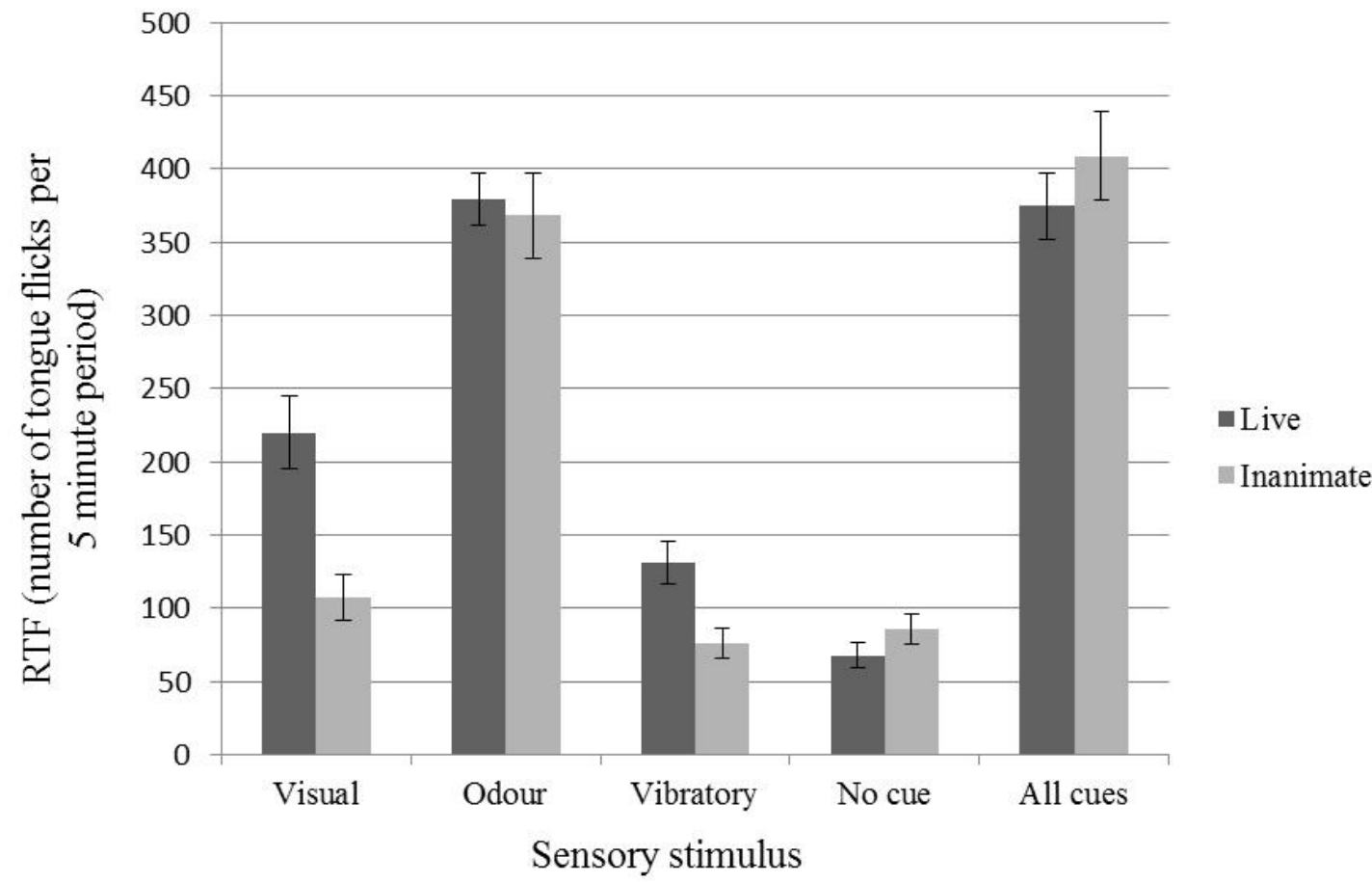

\section{0: $\quad$ Figure Captions}

Figure 1: $\quad$ Fig. 1. Mean RTF (rate of tongue flick) $( \pm \mathrm{SE})$ in response to live and inanimate sensory stimuli 
